\title{
The Role of Mega Projects in Redefining Housing Development in Gulf Cities
}

\author{
Florian Wiedmann, Ashraf M. Salama, and Hatem G. Ibrahim
}

\begin{abstract}
:
Since the end of the 1990s large scale mega projects have been initiated in Gulf cities to enable an unprecedented urban growth and the expansion of new economic sectors. In this respect, mega projects have played a key role in redefining housing developments in Gulf cities. This paper explores the newly emerging housing typologies and their distinctive roles in defining new urban environments. The selected case studies are located in the Jumeirah District in Dubai, which can be seen as the first prototype of a large cohesive development area that has been built of nine rather differing mega projects including the iconic Palm project and one of the largest residential high-rise agglomerations in the Middle East. The paper is based on the evaluation of official planning data from each project and field observations. Conclusions are drawn to highlight key implications while identifying housing development tendencies.
\end{abstract}

Key words: Mega projects, housing, urbanism, Dubai, Gulf

\section{Introduction: The Evolution of Housing in Gulf Cities}

Until the oil production introduced modern urbanization, housing typologies have been the result of self-built processes within tribal societies and thus a direct expression of local culture, climate and available building materials. Furthermore, the migration of merchant families from Iran and India during the pearl trade era in the $19^{\text {th }}$ century has led to a certain knowledge-transfer of building techniques, such as the introduction of wind towers (Hawker, Hull and Rouhani, 2005). Each neighborhood, known as fereej, was inhabited by homogeneous social groups, often related to each other (Pallathucheril, p. 99, 2015). The typical family dwelling was the introverted courtyard house, usually attached to surrounding buildings (Wiedmann, Salama and Thierstein, 2012, p. 36).

The first phase of rapid urbanization commenced in the middle of the $20^{\text {th }}$ century and was enabled by the quick reinvestment of first oil revenues in infrastructure projects including basic road networks and utilities. The subsequent migration from rural areas in addition to the vast migration of millions of guest workers led to first urban agglomerations, whose structure was mainly defined by first infrastructural networks. In general, two major phases of new housing developments have led to a completely new morphology of settlements in the Gulf region during the oil urbanization:

Firstly, the arrival of the rural native population in combination with the general objective to increase living conditions caused the development of low-rise residential areas in the periphery of previous historic settlement cores. And second, the widespread move of a large part of the native population from central areas to these new suburban areas led to an extensive demolition process of traditional neighborhoods, which were replaced by modern multi-story developments (Hathloul and Mughal, 2004). This second phase of development had two major characteristics: The old central market areas were developed by the new road grid and subsequently expanded to become the main commercial districts. The first apartment buildings were built within and in proximity to these areas, where they replaced the traditional neighborhoods. The result of this transformation was an increasingly dense 
mixed-use downtown area surrounded by a sprawling residential urban periphery relying on the car as main mode of transportation (Figure 1) (Wiedmann, 2012, p. 26).

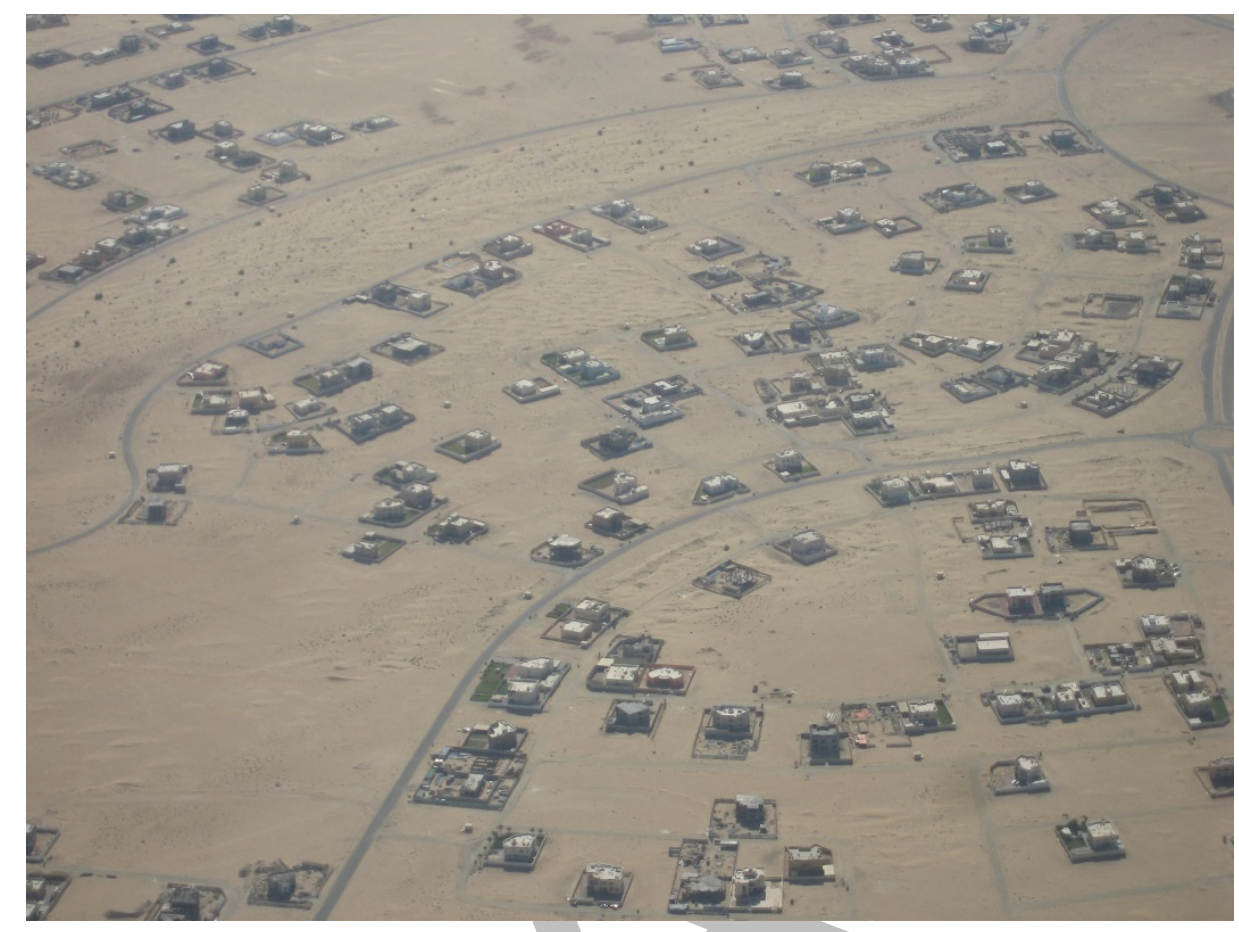

Figure 1: Suburban villas of native inhabitants in the United Arab Emirates. Source: Authors.

This rather basic urban structure and development pattern was followed during the subsequent decades and the emergence of first master plans during the 1970s (Scholz, 1999, p. 77). Thus, downtown areas became more and more densely built leading to first agglomerations of dense blocks and first towers, as it can be observed in the case of Abu Dhabi City, while suburban areas expanded due to the continuous distribution of residential land and subsequent infrastructural development, including the integration of shopping malls. The new shopping mall complexes enabled the urban periphery to increasingly detach from the old historic market areas, which have gradually lost their previous significance as main retail centers and leisure spaces for all inhabitants, while most working places hardly moved from central areas and commercial growth corridors (Salama and Wiedmann, 2013, p. 33).

At the end of the $20^{\text {th }}$ century a new development vision was introduced to establish Gulf cities as international hubs in order to diversify local economies. This new development phase was first initiated in cities, such as Dubai and Manama, where the local oil production receded. But due to the rapid impact on urban and thus economic growth, the new development strategies were adopted in various cities, including Doha and Abu Dhabi, where the production of oil and gas has enabled the public sector to reinvest revenues in new economic development strategies (Schmid, 2008 and 2009). This new phase of economic transformation is mainly rooted in the vision to establish oil-independent service economies by benefiting from the fortunate geopolitical location between regional and global markets. This vision was followed by distinctive public investment strategies in infrastructure, services and certain landmark developments in combination with the liberalization of markets by introducing free economic 
zones and by permitting regional and foreign investors to participate in local real-estate markets (Fox, Mourtada-Sabbah and Al-Mutawa, 2006).

Consequently, the resulting construction boom has led to a second major urban transformation process in Gulf cities. Large scale developers and their mega projects have begun to play key roles in developing large areas of desert land in a very short period of time. Housing markets themselves have furthermore diversified due to the move of higher income migrant groups engaged in the new service economies. This paper therefore explores the new housing typologies, which have been the result of recent development dynamics and which have redefined urban environments in Gulf cities in most recent years.

\section{Methodological Approach}

This paper is based on an analysis and evaluation of all key mega projects, which have been developed in Dubai's Western Jumeirah district, which is also known as New Dubai, since 1999. In comparison to other Gulf cities mega projects in Dubai are the product of an intense development period of more than 16 years and are thus more diversified and can look back on various planning modifications. Dubai can furthermore be seen as a role model and thus testing ground of various new housing typologies in terms of market dynamics.

The basic empirical research for this paper includes the collection of all key data for each mega project, such as the projected population, the number of housing units, the basic land uses and the built typologies. This data was mainly collected from developers and their official websites. Furthermore, site visits were used to explore the current state of development. The new master planning efforts from the Dubai Municipality were furthermore evaluated regarding the general role of the Jumeirah districts and the multitude of mega projects.

\section{The Case of New Dubai}

The New Dubai district in Western Jumeirah became the first address for residential freehold property developments after the Emirates Golf Club was founded in 1988 and several hotels including the Burj Al Arab were built during the 1990s along Jumeirah's coast. The new district extension is located at the Western coastline in a distance of around 20 kilometers from the old center at the Dubai Creek. The district is part of the main growth corridor along Sheikh Zayed Road towards Jebel Ali and the Emirate of Abu Dhabi (Figure 2). The convenient location and already existing infrastructural supply due to the main highways prompted the developer Emaar to build its very first freehold property project, called Emirates Hills, in New Dubai in 1999. 


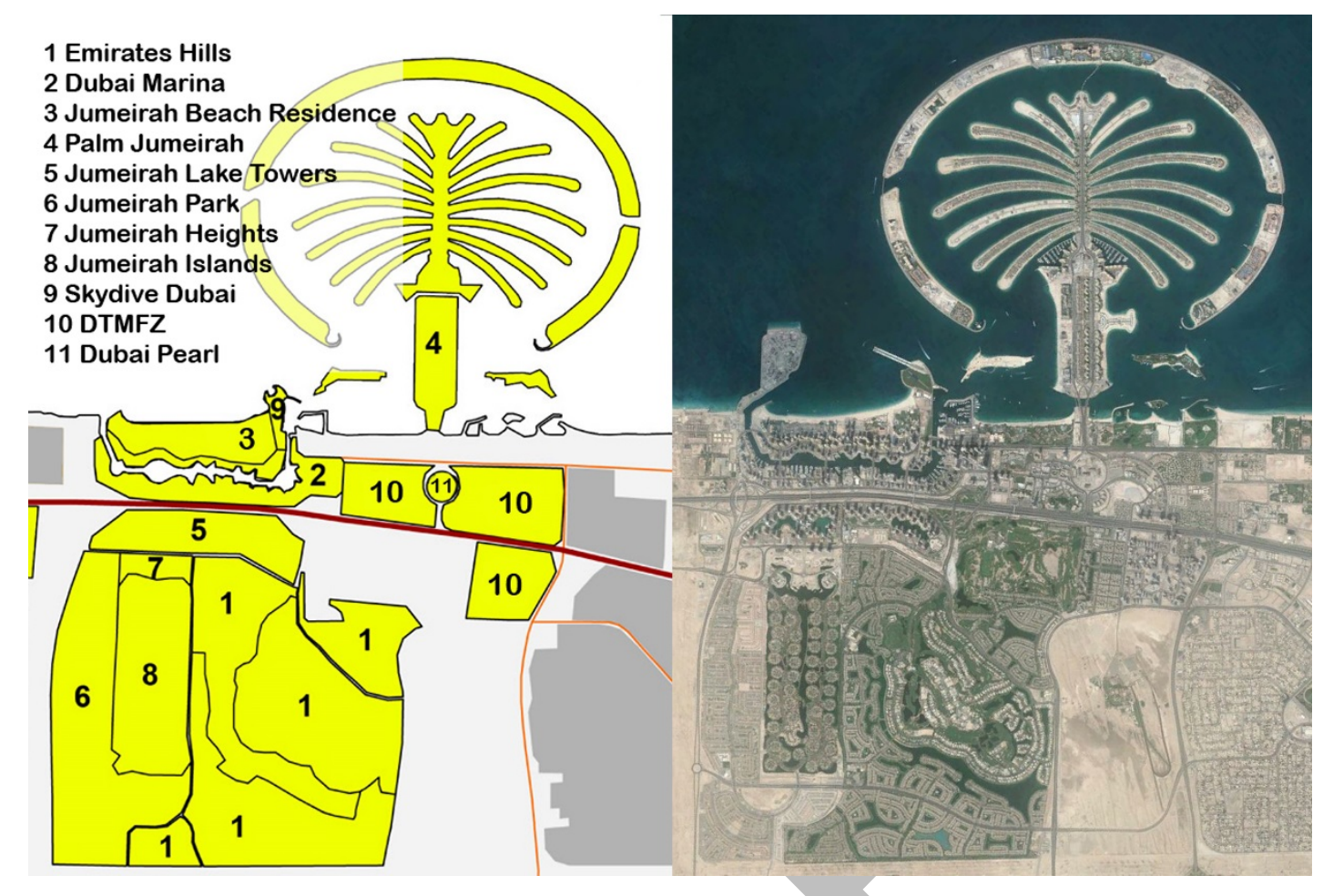

Figure 2: The New Dubai district and its nine main mega projects. Source: Authors and Google Earth.

Over the course of the following years the Emirates Hills project was expanded through several developments including the Springs, the Meadows, the Lakes, the Views and the Greens into one large development area called Emirates Living, which is home to approximately 40,000 people. The whole area is about 12.3 square kilometers and is predominantly occupied by two-story villas (Emirates Living, 2015). Apartment buildings were built within the projects the Views and the Greens as well as within several smaller projects in the north of the development. In the case of Emirates Hills, the master developer Emaar has built the basic infrastructure and provided freehold properties in the form of undeveloped large-scale plots of about $40 \times 100$ square meters, which have been designed and constructed individually by each individual investor. Most areas of the neighboring projects however were developed by the master developer itself by constructing a reduced set of different types of villa. The special feature of Emirates Living is the vast area of unbuilt land in the form of more than 20 artificial lakes and a golf course occupying more than $35 \%$ of the whole development. Furthermore, instead of an orthogonal road network, an ornamental layout was chosen for the developments, creating an individual structure with winding streets.

Apart from these suburban housing areas, which have been set up as semi-gated communities, several new 'free economic zones' have been developed in order to create business areas close to the new suburbs. In 2000, Dubai Internet City (DIC) was established as the first free zone in Jumeirah providing optimized business opportunities for international technology, software and internet companies such as HP, Microsoft, IBM and Siemens. In 2009, more than 1,200 companies were already settled in DIC, creating more than 10,000 jobs (Dubai Internet City, 2015). In addition to DIC, the company TECOM, which was established as a subsidiary of Dubai in order to invest in the knowledge-based economy, launched Dubai Media City (DMC) in 2001. In 2003, TECOM initiated the development of Dubai Knowledge Village (DKV) as part of the overall free zone conglomerate represented by the Dubai 
Creative Clusters Authority (DCCA). Various residential projects, such as large compounds with villas and low-rise apartment buildings in addition to few residential towers have been integrated (Figure 3 ). The free zone is situated between Sheikh Zayed Road and the coast with an area in the south-east covering about 350 hectare to allow for future expansion. In the center of the conglomerate, the construction of the project Dubai Pearl has been started on a circular area to form a commercial center and a residential complex of connected high-rise buildings to house approximately 29,000 residents and visitors (Dubai Pearl, 2015).

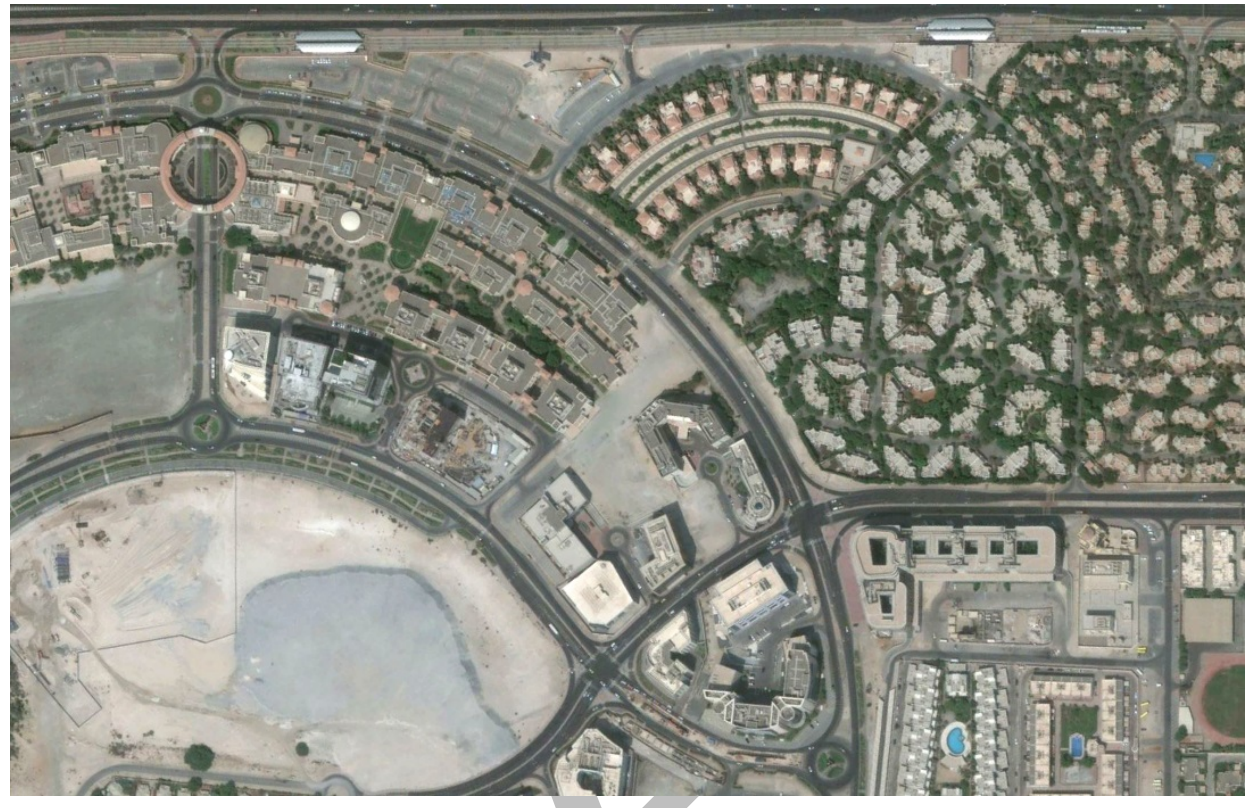

Figure 3: The various compound developments within the Dubai Internet City and Dubai Media City. Source: Google Earth.

A bypass leading from TECOM's Dubai Internet City and Media City forms the starting point of one of Dubai's biggest landmarks - the Palm Jumeirah. A 300-metre long bridge leads to the beginning of the artificial islands, which are shaped in the form of a palm with a 2-km long trunk and 16 fronds protected by an 11-km long crescent functioning as a breakwater. In addition to a monorail, which runs from the crescent over a bridge and down the trunk to the coast, an 800-metre long tunnel at the top of the palm connects the crescent to the palm. Since 2001, more than 92 million cubic meters of sand have been needed to create the whole land mass on an area of about 550 hectare, which has added about $78 \mathrm{~km}$ of new coast line. Since 2009 1,400 villas and 20 multi-story apartment buildings provide about 2,500 housing units (Figure 4). The whole project covers an area of $5 \times 5 \mathrm{~km}$ and mainly consists of luxury freehold properties and 32 hotels and resorts (Nakheel (1), 2015). 


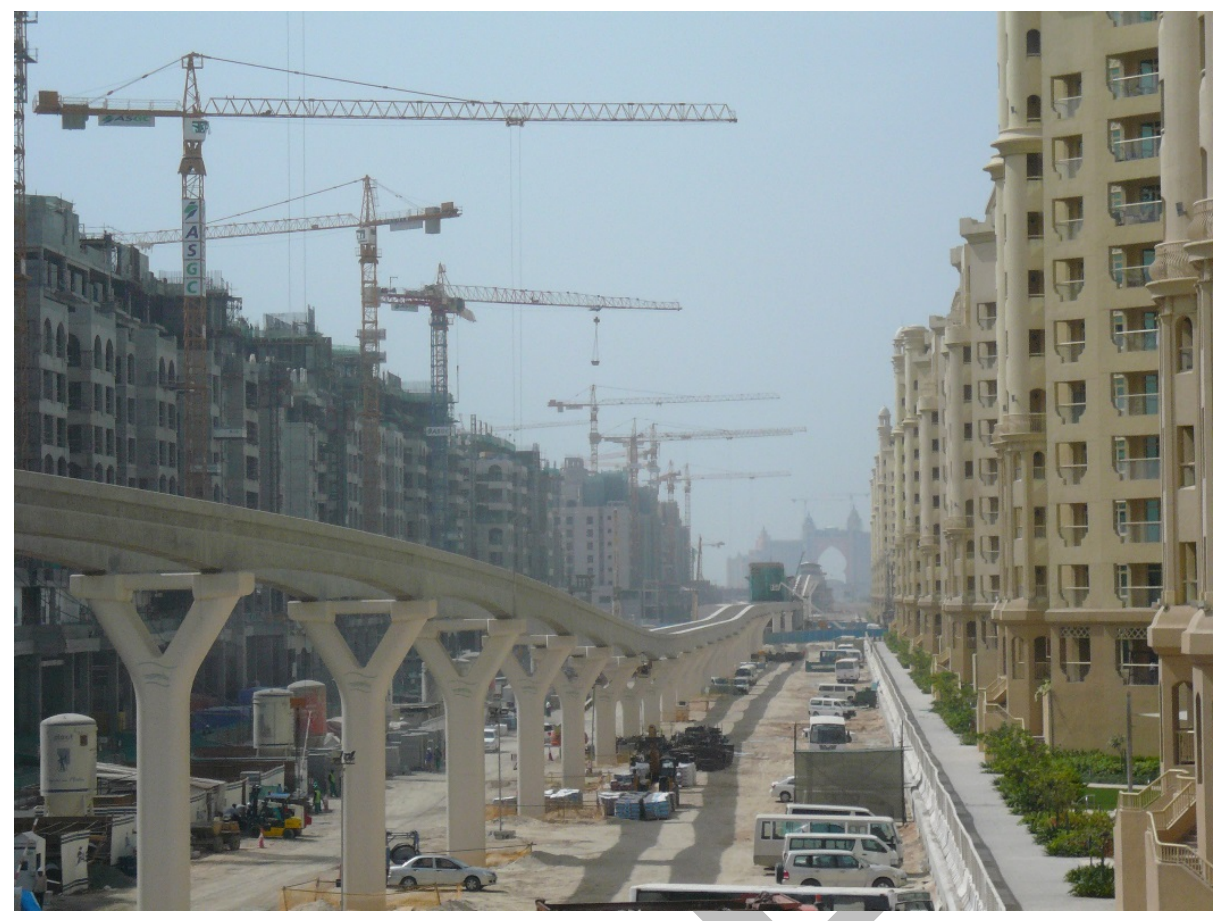

Figure 4: The apartment buildings at the trunk of the Palm Jumeirah under construction in 2008. Source: Authors.

In addition to the growing number of residence units on the Palm project itself, it has attracted new housing projects along the coast offering views on the artificial islands. One of these developments is Emaar's Dubai Marina, a conglomerate of residential high-rise buildings along one of the largest manmade marinas in the world. Since 2003, the project has been developed in different stages on an area of around 400 hectare for more than 100,000 future residents (Emaar, 2015). In the year 2014 Dubai Marina housed 28,361 inhabitants, which is an indicator for a rather high vacancy rate in spite of several tower projects still under development (Dubai Statistics Authority, 2014). After a 3.6-kilometer long artificial channel was dug, the first residential towers were built in the east of the project as well as the promenade along the marina (Figure 5). Most of the towers have an average height of between 130 and 200 meters and are generally designed as freehold properties offering various sizes of apartments for the upper real estate market. About nine high-rise buildings are currently being developed with a height of over 300 meters, including the 516-metre tall Pentominium, which is still under construction. 


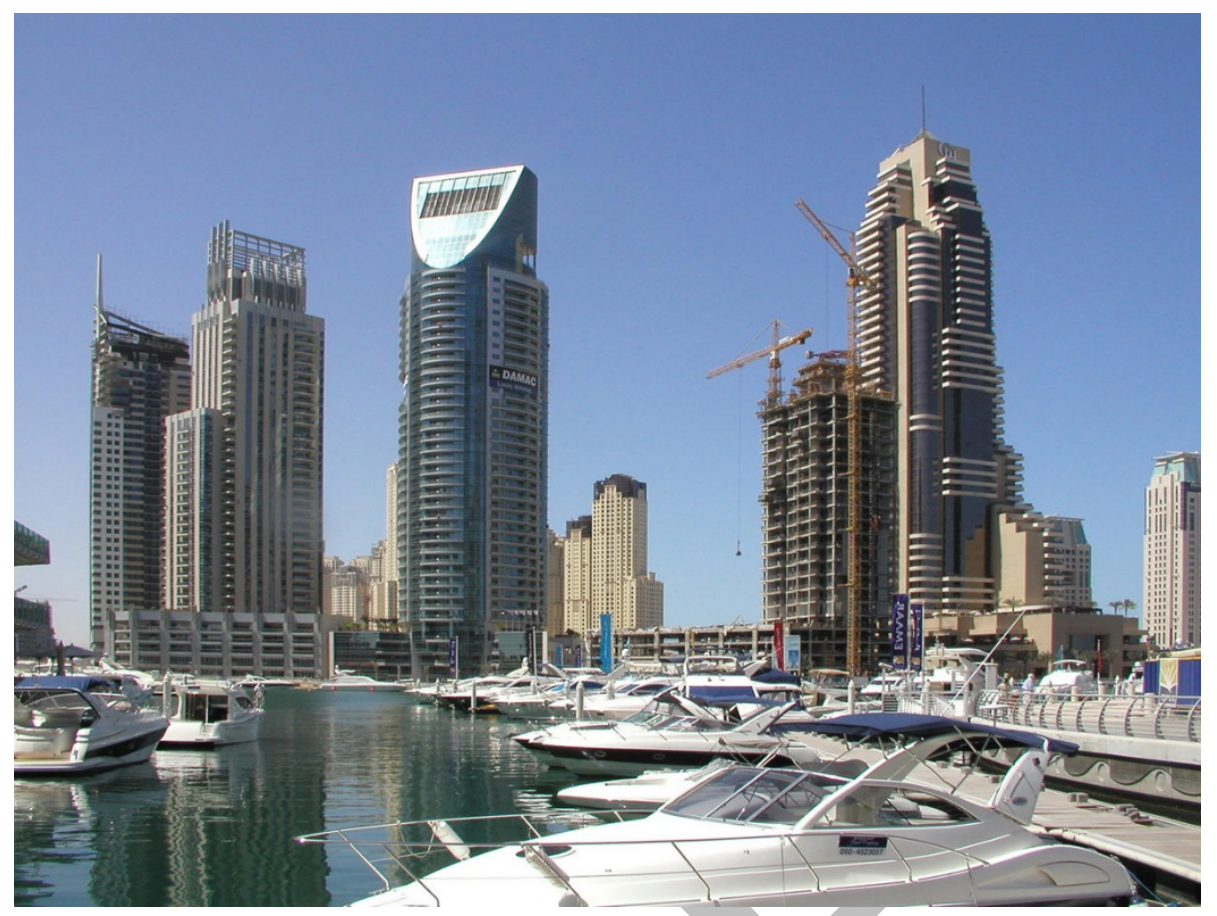

Figure 5: The Dubai Marina project and its residential towers. Source. Authors.

Between the coast and Emaar's Dubai Marina, a second residential high-rise development for about 30,000 residents was completed by Dubai Properties in 2007 - the Jumeirah Beach Residence includes 36 residential towers and four hotel towers spreading along the 1.7-km long shoreline (Figure 6) (Dubai Properties, 2015). The third and second largest development of a high-rise conglomerate in Jumeirah is Nakheel's Jumeirah Lake Towers stretching over an area of 180 hectare on the opposite side of Sheikh Zayed Road along the Dubai Marina. The whole development is known as the first mixed-use free economic zone of Dubai, including 79 towers, which predominantly are residential towers for more than 60,000 people and office towers for more than 120,000 working visitors. The towers with 35 to 45 floors are clustered in groups of three, surrounded by four artificial lakes covering an area of about 18 hectares. In the South of the project, Nakheel has developed a smaller high-rise project called Jumeirah Heights offering about 2,300 residences within four high-rise buildings and six multi-story apartment blocks (Nakheel (2), 2015). 


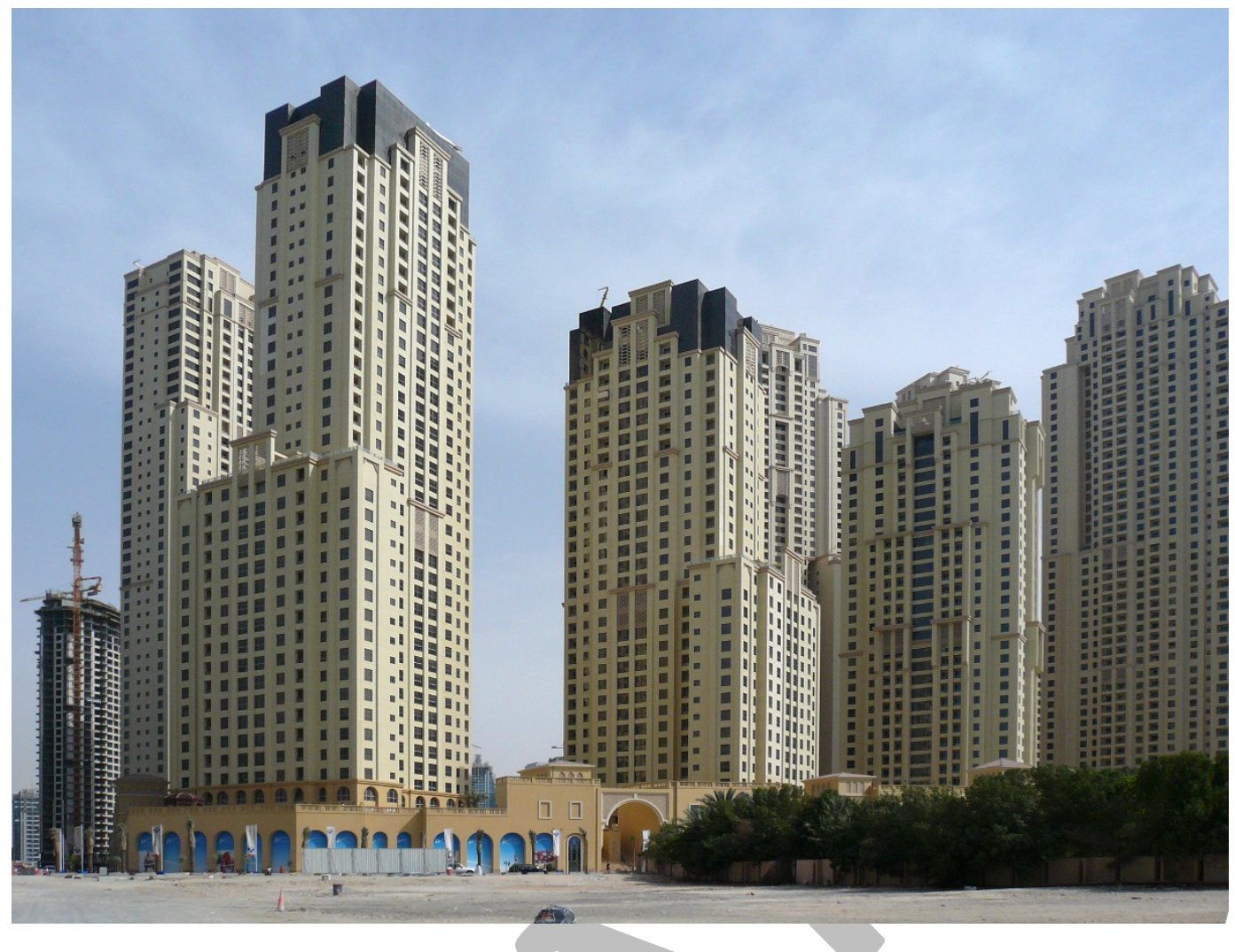

Figure 6: The Jumeirah Beach Residence. Source: Authors.

The project Jumeirah Heights marks not only the end of what is currently Dubai's biggest high-rise agglomeration, it is also designed to be part of another signature project of Nakheel in Jumeirah - the Jumeirah Islands. The 300-hectare development consists of 46 clusters of man-made islands surrounded by artificial lakes. The 736 villas have been developed in different sizes in order to attract various investors. Along the borders of this development Nakheel has launched the project Jumeirah Park, which includes 2,000 villas and about 10 apartment buildings in the center on an area of more than 350 hectares. Around three different architectural designs and nine different sizes of villa have been developed for the entire project (Nakheel, 2015).

Most development sites of the nine mega projects in New Dubai have been developed since the beginning of the new millennium. All projects in New Dubai aim for the upper real-estate market with rents exceeding AED 100,000 per annum. Today, it is estimated that there is an oversupply of $40 \%$ in this segment leading to high vacancy rates in many developments in New Dubai (World Property Journal, 2015). All projects combined have been designed for an expected total population of around 275,000 inhabitants in future. The whole built area, excluding the main high-way infrastructure, is covering almost 29 square kilometers, which is leading to a rather moderate future average urban density of less than 95 inhabitants per hectare (Table 1). In comparison, New Dubai is about half the size of Manhattan Island, where around 277 inhabitants reside per hectare. 


\begin{tabular}{|c|c|c|c|c|c|c|}
\hline Project name & Developer & $\begin{array}{c}\text { total } \\
\text { area (sq } \\
\text { km) }\end{array}$ & $\begin{array}{l}\text { expected } \\
\text { population }\end{array}$ & $\begin{array}{c}\text { Urban } \\
\text { density } \\
\text { (residents } \\
\text { per hectare) }\end{array}$ & Development type & Typology \\
\hline Dubai Marina & Emaar & 4 & 100,000 & 250 & $\begin{array}{c}\text { Residential, retail \& } \\
\text { leisure }\end{array}$ & High-rise \\
\hline $\begin{array}{l}\text { Jumeirah Beach } \\
\text { Residences }\end{array}$ & Nakheel & 0.17 & 30,000 & 1,765 & $\begin{array}{c}\text { Residential, retail \& } \\
\text { leisure }\end{array}$ & High-rise \\
\hline $\begin{array}{l}\text { Jumeirah Lake } \\
\text { Towers }\end{array}$ & Nakheel & 1.8 & 60,000 & 333 & $\begin{array}{c}\text { Residential \& } \\
\text { commercial (offices) }\end{array}$ & High-rise \\
\hline $\begin{array}{l}\text { Jumeirah } \\
\text { Heights }\end{array}$ & Nakheel & 0.6 & 6,000 & 100 & Residential & High-rise \\
\hline Jumeirah Park & Nakheel & 3.5 & 6,000 & 17 & Residential & Low-rise \\
\hline $\begin{array}{l}\text { Jumeirah } \\
\text { Islands }\end{array}$ & Nakheel & 3 & 2,000 & 7 & Residential & Low-rise \\
\hline Emirates Living & Emaar & 12.3 & 40,000 & 33 & Residential & Low-rise \\
\hline $\begin{array}{l}\text { DIC and DMC } \\
\text { (DCCA) }\end{array}$ & TECOM & 3.5 & 2,000 & 6 & $\begin{array}{l}\text { Commercial (free } \\
\text { zone) \& residential }\end{array}$ & Mixed \\
\hline Dubai Pearl & $\begin{array}{l}\text { Al Fahim } \\
\text { Group }\end{array}$ & 0.1 & 29,000 & 2,900 & $\begin{array}{c}\text { Residential \& } \\
\text { commercial (offices) }\end{array}$ & High-rise \\
\hline \multicolumn{2}{|l|}{ Total } & 28.97 & 275,000 & 95 & & \\
\hline
\end{tabular}

Table 1: The key facts of the nine mega projects in New Dubai. (Source: Authors \& official developers'

\section{Housing Development Tendencies in Gulf Cities}

Based on the case studies in New Dubai four distinctive new housing typologies can be distinguished: (1) The waterfront villa, (2) the waterfront tower, (3) the free-zone housing and (4) the suburban mega compound (Figure 7).

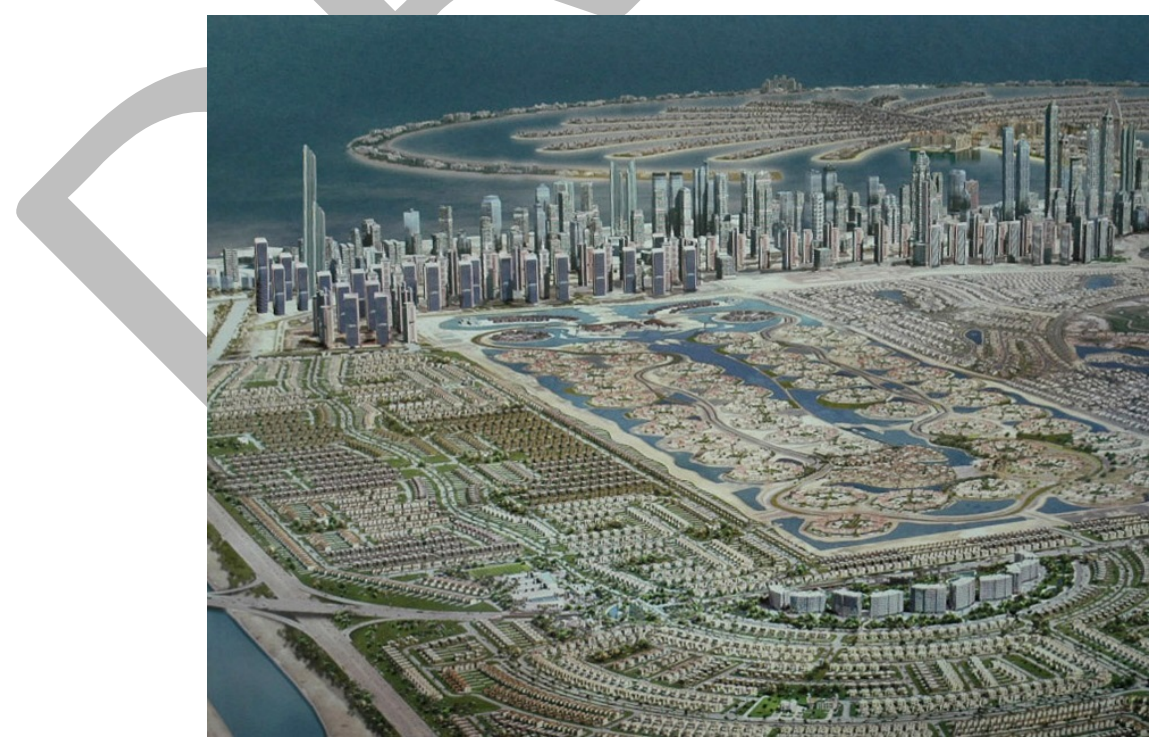

Figure 7: The four new typologies in the case of New Dubai. Source: Authors. 
While waterfront villas and their private beach access are mainly the result of particular land reclamation patterns and restrained infrastructural opportunities to build higher densities, the tower developments along the coast are the result of rapidly increasing land prices, fueled by speculations regarding sea view properties. The large quantity of towers has however led to very limited access to sea views in the case of most properties. The residential tower clusters are often supplied with a variety of leisure spaces, such as integrated marinas, beaches, malls and promenades. This high-level of diversity regarding consumption and leisure spaces is based on both the average income of residents and the attraction of tourists due to integrated hotel complexes. The supply of social infrastructure is however often very limited. Thus, it can be observed that there is a big lack of schools within and in proximity to waterfront tower clusters due to missing regulations and high land prices in areas reserved for exclusive projects.

The development of mixed-use and themed free economic zones has led to the establishment of various integrated compound developments, which are differing from the usual compound sites due to their particular surroundings. The compounds are built between the various office complexes and usually house employees and their families engaged in the free zones. The residential projects often include various typologies from attached and detached villas to apartment blocks. In some cases compounds will be replaced by commercial developments depending on future demand, which is creating an environment of temporary rather than long-term neighborhoods. The walls of each compound are furthermore contributing to the fragmented appearance and the general lack of accessible public spaces within free zones.

The last new housing phenomenon are large-scale themed suburban gated communities. Their development sites can occupy large areas of many square kilometers and their monotonous typologies of attached and detached dwellings as well as low-rise apartment blocks mainly differ from each other due to ornamental road grids, which are used to create individual spatial patterns. This has however led to rather detached and introverted residential areas with hardly any links than major highways.

Subsequently, neighborhood centers and social infrastructure have been developed in disperse locations depending on land availability rather than on a clear strategy to create integrated and accessible subcenters for services and facilities. In some large scale projects certain leisure spaces, such as golf courses, water features and small malls, have been integrated to enhance the general attractiveness.

In summary, it can be stated that the recent mega projects have led to new urban landscapes, which are defined by new housing typologies and their spatial distribution (Figure 8 ). The emerging island projects have led to a variety of suburban settlements on reclaimed land with limited access and a high level of exclusivity. In parallel large scale themed suburban mega projects have been launched towards inland along the urban periphery of former urban centers. The coastal transition zones are usually occupied by extending agglomerations of residential tower developments, which are the direct consequence of high land prices and already existing infrastructural supply. And last but not least new themed mixed-use developments, which are often initiated as free economic zones along strategic growth corridors, integrate various residential typologies as either short-term housing supply depending on the demand on commercial projects or as exclusive but often rather isolated freehold property projects benefiting from the overall branding of developments as new cities within the city. 


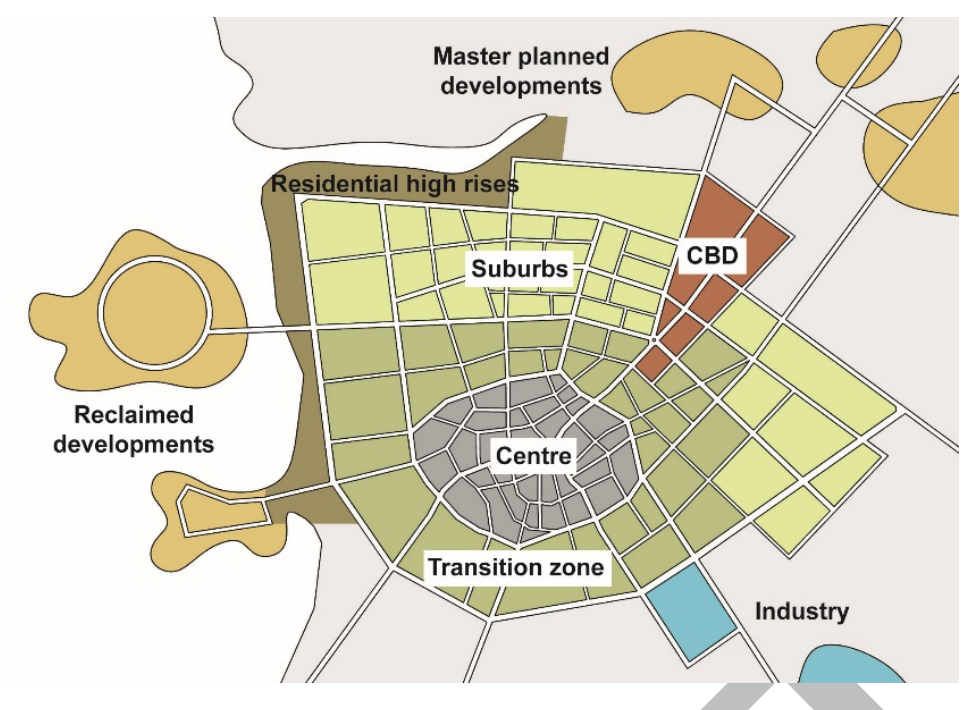

Figure 8: The typical structure of contemporary Gulf cities. Source: Authors.

All these development types have mainly been a result of public investment strategies as well as investment pressure of the private sector. Today they are housing a growing migrant community with medium to high income. The ground floor plans have been designed following international standards rather than accommodating local or other distinctive cultural lifestyles. While in the past urban densities and land use distributions were centrally administered by one planning department, the mega projects are usually the result of a certain decentralization process permitting large scale developers, who are usually semi-public entities, a certain level of authority regarding master plans and hardly any regulation regarding the integration of social infrastructure or affordable housing.

The result has been an island-development approach following the general attitude of developing standalone "mega" compounds rather than integrated and cohesive new urban areas forming districts and neighborhoods. Thus, while housing typologies have been diversified by the various mega projects, there has hardly been any spatial reinvention of a new form of communities. A high-rise tower thus functions like a vertical compound rather than an opportunity to develop a new level of integrated public spaces and services. Thus, the only true social meeting points are provided by indoor malls and a small number of promenades along the coast as well as scattered green areas.

\section{Conclusion}

Housing has become one of the most favored commodities in Gulf cities. While trading pearls led to first port cities in the $19^{\text {th }}$ century, trading oil and gas led to expanding cities with one of the lowest average urban densities worldwide. The recent trading with real-estate has led to a diversity of themed worlds inviting for leisure and consumption (Figure 9), but hardly integrating any sense of community and neighborhood. The exponential real-estate prices have furthermore led to a continuous increase of rental rates leading to an enhanced social segregation and the phenomenon of high vacancy rates and over-occupied properties, particularly in the case of more dated projects. Both the under-occupation due to high rental prices and the over-occupation due to single migrants sharing apartments or villas have led to disparities from area to area and thus insufficient infrastructural supply. 


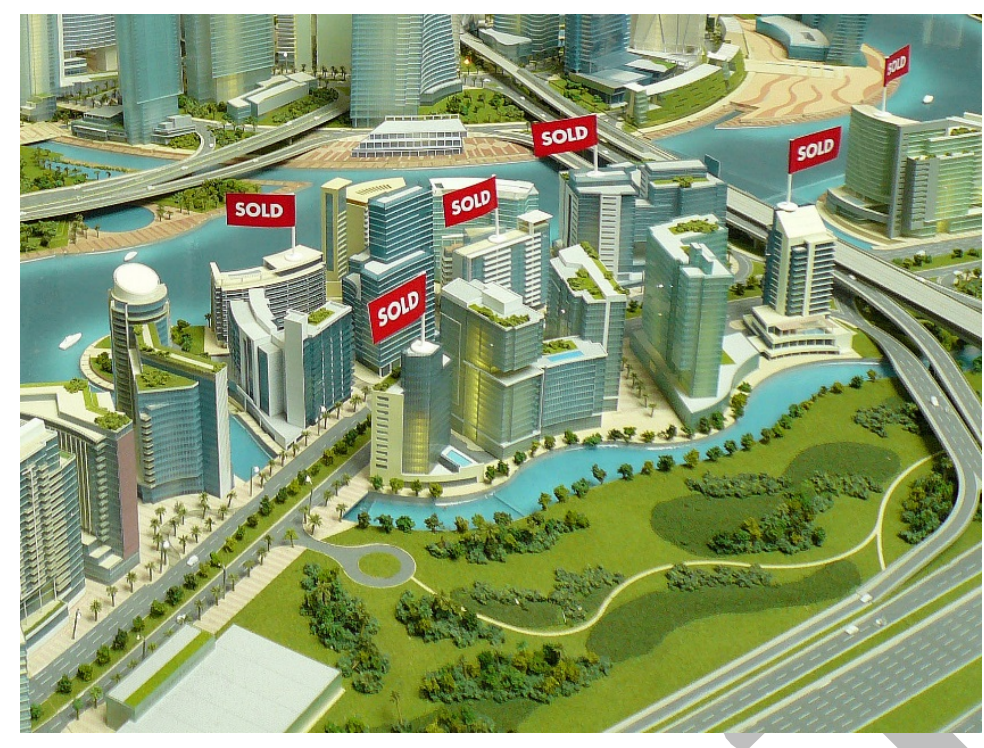

Figure 9: Housing as new prime commodity in Gulf cities. Source: Authors.

The new role of housing as investment opportunity in Gulf cities has attracted both regional and global attention and has thus undoubtedly led to a large-scale diversification of housing types. While the big variety of differing typologies can be observed by analyzing the entire spectrum of recent real-estate projects, the mass development of housing has led to rather monotonous urban spaces from the perspective of single projects and their immediate surroundings. The repeated architectural design and modular construction of hundreds of new dwellings have contributed to a highly disorienting housing environment. The missing neighborhood centers, social services and accessible public spaces have furthermore contributed to a lack of identity and the remaining dependency on commuting by car, which documents the suburban role of most mega projects rather than the establishment of selfcontained settlements.

Consequently, it can be stated that mega projects have introduced new housing opportunities for upper income groups, particularly various apartment types, which have become suitable representations of social status in Gulf cities. The needed diversification of housing, which was previously mainly dominated by suburban villas, has however not led to an enhanced urban identity and efficiency in the case of single districts and urban spaces. In most cases developers have labelled housing projects as new communities rather than integrating needed infrastructure and public spaces to actually create future communities. The lack of affordable housing schemes has furthermore contributed to social segregation and a rather fragile environment of repetitive exclusive projects relying on future economic growth in order to avoid a complete challenging of their existence as displayed in the recent financial crisis.

\section{Acknowledgements}

This paper is developed as part of a comprehensive funded research project of the National Priorities Research Program, QNRF-Qatar National Research Fund (NPRP 7 - 960 - 5 - 135).

\section{References}


Al HATHLOUL, S. and MUGHAL, M. A. 2004. Urban growth management the Saudi experience, in Habitat International, 28, 609-623.

DUBAI INTERNET CITY. Who we are. Retrieved 14 December, 2015 from http://www.dic.ae/who-weare/\#get_intouch

DUBAI STATISTICS CENTRE. Population 2014. Retrieved 14 December, 2015 from https://www.dsc.gov.ae/Publication/Population\%20Bulletin\%20Emirate\%20of\%20Dubai\%202014.pdf DUBAI PEARL. Project. Retrieved 14 December, 2015 from http://www.dubaipearl.com/project DUBAI PROPERTIES. Jumeirah Beach Residence. Retrieved 14 December, 2015 from http://dp.ae/portfolio/jumeirah-beach-residence-62

EMAAR. Dubai Marina Waterfront. Retrieved 14 December, 2015 from https://www.emaar.com/en/what-we-do/communities/uae/dubai-marina/ EMIRATES LIVING. Emirates Hills. Retrieved 14 December, 2015 from http://www.emiratesliving.ae/en/about/communities/emirateshills.aspx FOX, J. W., MOURTADA-SABBAH, N., and AL-MUTAWA, M. 2006. Globalization and the Gulf, Routledge, New York.

HAWKER, R., HULL, D. and ROUHANI, O. 2005. Wind-towers and pearl fishing: architectural signals in the late nineteenth and early twentieth century Arabian Gulf, in Antiquity: A Review of World Archaelogy, 79 (305), 625-635.

NAKHEEL (1). Palm Jumeirah. Retrieved 14 December, 2015 from

http://www.nakheel.com/en/communities/palm-jumeirah

NAKHEEL (2). Jumeirah Heights. Retrieved 14 December, 2015 from

http://www.nakheel.com/en/communities/jumeirah-heights

PALLATHUCHERIL, V. 2015. New Hearts for Two Gulf Cities. In Katodrytis, G. and Mitchell, K. (eds.), UAE and the Gulf: Architecture and Urbanism Now, Architectural Design, 233, 92-106.

SALAMA, A. M. and WIEDMANN, F. 2013. Demystifying Doha: On Architecture and Urbanism in an Emerging City, Ashgate Publishing Limited, Surrey.

SCHMID, H. 2008: Ökonomie der Faszination - Dubai und Las Vegas als Beispiele inszenierter Stadtlandschaften, Habilitation, Ruprecht-Karls-Universität Heidelberg. 
SCHMID, H. 2009. Dubai: Der schnelle Aufstieg zur Wirtschaftsmetropole, in Blum, E. and Neitzke, P. (eds.), Dubai - Stadt aus dem Nichts, Birkhaeuser, Berlin.

SCHOLZ, F. 1999. Die kleinen Golfstaaten. 2nd Edition. Justus Perthes Verlag GmbH, Gotha.

WIEDMANN, F. 2012. Post-oil Urbanism in the Gulf: New Evolutions in Governance and the Impact on Urban Morphologies. SVH Verlag, Stuttgart.

WIEDMANN, F., SALAMA, A. M. and THIERSTEIN, A. 2012. Urban Evolution of the City of Doha: An Investigation into the Impact of Economic Transformations on Urban Structures, in JFA/METU: Journal of the Faculty of Architecture, 29(2), 35-61.

WORLD PROPERTY JOURNAL. Dubai Property Correction Overshadowed by 5-Year Supply Mismatch. Retrieved 14 December, 2015 from http://www.worldpropertyjournal.com/real-estate-news/dubaiuae/dubai-property-report-2015-phidar-advisory-dubai-residential-research-report-condo-prices-indubai-jesse-downs-9142.php

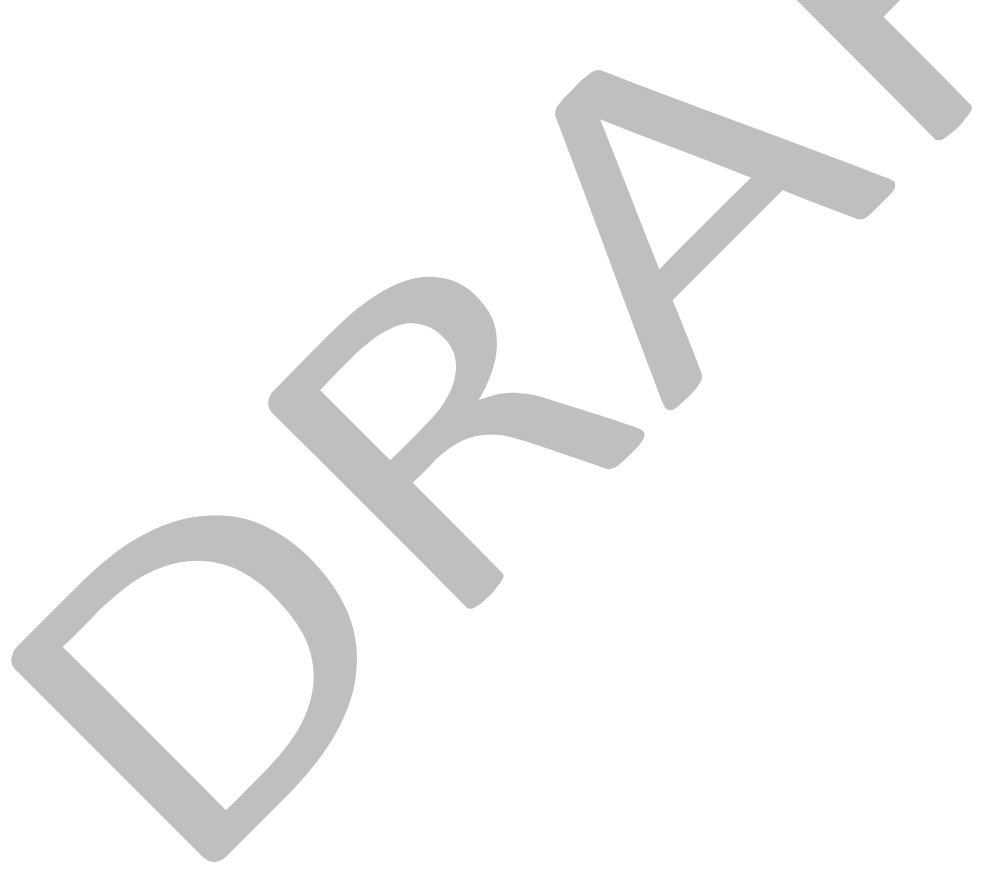

